\title{
Intersections
}

Canadian Journal of Music

Revue canadienne de musique

\section{Ryan McClelland. 2010. Brahms and the Scherzo: Studies in Musical Narrative. Burlington: Ashgate Publishing. 320 pp. ISBN 978-0-75-466810-7}

\section{René Rusch}

Volume 30, numéro 2, 2010

URI : https://id.erudit.org/iderudit/1006384ar

DOI : https://doi.org/10.7202/1006384ar

Aller au sommaire du numéro

Éditeur(s)

Canadian University Music Society / Société de musique des universités canadiennes

ISSN

1911-0146 (imprimé)

1918-512X (numérique)

Découvrir la revue

Citer ce compte rendu

Rusch, R. (2010). Compte rendu de [Ryan McClelland. 2010. Brahms and the Scherzo: Studies in Musical Narrative. Burlington: Ashgate Publishing. 320 pp. ISBN 978-0-75-466810-7]. Intersections, 30(2), 127-130.

https://doi.org/10.7202/1006384ar

All Rights Reserved (C) Canadian University Music Society / Société de musique des universités canadiennes, 2011
Ce document est protégé par la loi sur le droit d'auteur. L'utilisation des services d'Érudit (y compris la reproduction) est assujettie à sa politique d'utilisation que vous pouvez consulter en ligne.

https://apropos.erudit.org/fr/usagers/politique-dutilisation/ 
Sigismund Neukomm wrote for the album of his friend Luigi Cherubini, who had long been a teacher of counterpoint at the Paris Conservatoire. In the final essay, Ronald Woodley shows how canonic reiteration seems to have been an obsession in the works of Steve Reich, since his "phase shifting" and tape-loop experiments of the 1960s until and beyond his composition of Proverb (1995), based on an Wittgenstein's aphorism "Welch ein kleiner Gedanke doch ein ganze Leben fullen kann" (How small a thought it takes to fill a whole life).

Bravo to the editors for a goodly assembly of thoughtful essays on the art of counterpoint developing through two centuries, as reflected through the prism of distinguished musicologists. Such a collection of essays selected for a conference must necessarily suffer from a certain incongruity and lacuna; thus one may quibble about the under-representation of some wonderful music, like the first printed collection of Latin and French canons that have appeared on the Chansons et Motetz [sic] website of the OICRM at the University of Montreal; but most of the best of Renaissance canons are represented here with a critical reflection and insight that will enhance any reader's understanding and enjoyment of this fascinating repertoire.

Frank DobBins

Ryan McClelland. 2010. Brahms and the Scherzo: Studies in Musical Narrative. Burlington: Ashgate Publishing. 320 pp. ISBN 978-0-75-466810-7.

What began in the 1980s as an exploration of the relationship between music and narrative has tentatively become a subdiscipline in current music scholarship. From Carolyn Abbate's queries about how the music from Dukas's The Sorcerer's Apprentice narrates, to Michael Klein's discussion of expressive states in Chopin's Fourth Ballade, scholars have examined the ways in which literary narratives can serve as an analogy for describing the dynamic processes we experience in music, calling into question not only whether music can narrate and signify, but also whether it has the capacity to convey a temporal past and present. ${ }^{1}$ Taking their departure from literary models, scholars have also proposed new theoretical frameworks that seek to confront the particular challenges that the music medium presents. ${ }^{2}$

Ryan McClelland's Brahms and the Scherzo: Studies in Musical Narrative contributes more broadly to this ongoing discussion on music and narrative by proposing that rhythm and metre play a primary role in motivic development, acting as "motivic agents whose journey is as central as the development

1 Carolyn Abbate, "What the Sorcerer Said," 19th-Century Music 12, no. 3 (Spring 1989): 221-30; see also a later version of this article in Unsung Voices: Opera and Musical Narrative in the Nineteenth Century (New Jersey: Princeton University Press), 30-60; Michael Klein, “Chopin's Fourth Ballade as Musical Narrative," Music Theory Spectrum 26, no. 1 (Spring 2004): 23-55.

2 See, for instance, Byron Almén's A Theory of Musical Narrative (Bloomington: Indiana University Press, 2008). 
of pitch motives" (5).3 Recalling Harald Krebs's work on metric dissonance in Schumann's music, McClelland views the metrical progressions and processes in Brahms's music as conveying metrical narratives, though he expands Krebs's theoretical premises to include formal and tonal processes. ${ }^{4}$ Through durational reductions, phrase-rhythm analyses, and Schenkerian voice-leading graphs, McClelland seeks to demonstrate how expressive meaning is created through the interaction between rhythmic-metric narratives and tonal narratives in thirty-five scherzo-type movements from Brahms's multi-movement instrumental works. He traces how the transformation of rhythmic-metric processes, in conjunction with tonal and formal ones, gives rise to expressive trajectories-here equated, at times, with "narrative" and also conceived more generally in terms of dramatic actions such as conflict, triumph, transcendence, and resignation.

McClelland organizes the scherzo-types in his comprehensive study according to subtypes, such as "neo-classical" scherzos (whose stylistic traits recall those found in the classical era), pastoral scherzos, and scherzos that undergo formal experimentation, focusing on Brahms's early- to mid-scherzo-type movements in the first half of the book, and mid- to late scherzo-type movements in the second half. In addition to examining the fourteen inner movements marked "scherzo," McClelland also includes the intermezzo from the Piano Quartet, op. 25, as well as the scherzo's predecessor, the minuet. Also considered are inner movements that explicitly omit genre designation, including those whose characteristic traits, style, and tempi gravitate away from the scherzo and appear to be more suggestive of a waltz. McClelland attributes this omission of identification in Brahms's later works to a "blending of elements from the minuet, scherzo, and character piece," calling to our attention the instability of genre distinctions between these types (12). Throughout the author's comprehensive study of these inner movements, we acquire a general sense of how the composer's approach towards rhythmic-metric processes and thematic development evolves, with the accompanying view that largescale narratives-especially that of conflict and resolution-gain momentum around the time of Brahms's first maturity in the 1860 (297).5

Given that McClelland's study of Brahms's scherzo-type movements is mostly situated within the context of prior discussions on rhythm, metre, and motivic development in Brahms scholarship as opposed to more recent studies in musical narrative, what broader implications does his premise for rhythmic-metric narratives have for studies in musical narrative? To begin,

3 See also McClelland's "Tonal Structure, Rhythm, Meter, and Motive in the Scherzo-Type Movements of Brahms's Chamber Music with Piano" (PhD diss., Indiana University, 2004).

4 Harald Krebs, Fantasy Pieces: Metrical Dissonance in the Music of Robert Schumann (New York: Oxford University Press, 1999). See also Frank Samarotto, “'The Body That Beats': Review of Harald Krebs's Fantasy Pieces: Metrical Dissonance in the Music of Robert Schumann," Music Theory Online 6, no. 4 (2000), http://www.mtosmt.org/issues/mto.oo.6.4/mto.oo.6.4.samarotto.html. Here Samaratto initially raises the question of the interaction between metrical dissonance and tonal structure.

5 See also James Webster, “Schubert's Sonata Form and Brahms's First Maturity," 19th-Century Music 2 (July 1978): 18-35, and 3 (July 1979): 52-71. 
the possibility that some scherzo-type movements appear to resist rhythmicmetric narratives in McClelland's analyses coincides with several scholars' desire to distinguish between narrative and non-narrative pieces. Most recent is Byron Almén's criteria for a non-narrative reading of a musical work with respect to musical topics. ${ }^{6}$ According to Almén, a non-narrative piece lacks contrast or opposition and may or may not include a topic.7 This notion that a musical conflict or opposition must be present in order for a narrative to emerge appears to resonate throughout most of McClelland's careful readings of Brahms's scherzo-type movements; rhythmic-metric narratives are noticeably scant in movements where metric conflicts are generally absent and metric dissonance and irregular hypermetric periodicity are perceived to play a limited role, as in the third movements from the Clarinet Trio in A minor, op. 114, and the Clarinet Sonata, op. 120, no. 1, as well as Menuettos I and II from the Serenade in D Major, op. 11. Rhythmic-metric narratives appear to be most operative in McClelland's analyses where both metric conflict and metric dissonance are more apparent, such as the third movements from the Piano Sonata in F Minor, op. 5, the String Quartet in B-flat Major, op. 67, and the Cello Sonata in F Major, op. 99. Here McClelland identifies two possible outcomes for these narratives: (1) minimal change between expressive states (op. 5, III); and (2) shift between expressive states, of which the most common trajectory is from conflict to triumph or from conflict to resolution (op. 67, III, and op. 99, III).

What makes McClelland's rendering of narrative more complex than most discussions of musical narratives is his distinction between rhythmic-metric narratives and tonal narratives. If we accept this premise, how do rhythmicmetric narratives - when operative-interact with tonal ones? Two likely outcomes emerge: one where both narratives coincide and the other where they diverge. One of the most persuasive examples of the former type that McClelland offers is the scherzo from Brahms's Piano Quintet, op. 34, where the movement's rhythmic-metric narrative-instability to resolution-coincides with that found in the tonal structure. With respect to the rhythmic-metric narrative in this movement, the author suggests that the "subplot" for the juxtaposition between the $6 / 8$ and $2 / 4$ conflicting metres is resolved in the coda's reworking of the 6/8 arpeggiation figure in a 2/4 metre. McClelland's readings of the Piano Trio in C Major, op. 87, and the Piano Trio in C Minor, op. 101, present instances where the rhythmic-metric narrative departs from the tonal narrative. In both pieces, the tonal narrative receives closure but the rhythmicmetric narrative remains unresolved. How these diverging "dissonant" narratives affect both multi-movement works' denouement and overall expressive trajectory is hinted at in the final chapter of the book, though, in the end, is left as a cliff-hanger that appears to exceed the scope of McClelland's study.

6 Almén, Theory of Musical Narrative, 68-95.

7 Ibid. Here Almén reads Schubert's "Wiegenlied," op. 98, no. 2, as a non-narrative with a lullaby topic (Type I) and Schoenberg's Six Little Piano Pieces, op. 19, no. 2, as a non-narrative without a musical topic (Type IX). 
Perhaps most advantageous for music narrative studies is that McClelland's focus on scherzo-type movements provides an opportunity to consider the relationship between expressive trajectories and formal types. ${ }^{8}$ Given that the scherzo-type movements examined generally share a three-part large ternary form (A-B-A), we are in a better position to understand why the formal trajectory of statement, departure, and return correlates with the two rhythmicmetric narrative outcomes that McClelland identifies. The possibility for either a minimal change between expressive states or a shift between expressive states seems readily assimilable to a form that calls for a musical return or repetition, whereby Brahms's treatment of both the repetition of the second A section and post-cadential material in the final coda section greatly sways the outcome of the rhythmic-metric narrative reading. Although this linkage between expressive trajectories and formal patterns is not central to McClelland's study, the possibility of an expressive trajectory where minimal or no change in expressive states occurs could be a first step towards developing a narrative model that addresses the problem of repetition in music.

These implications aside, what also emerges from McClelland's approach to Brahms's scherzo-type movements is a larger issue that impinges on the vitality of music-narrative studies as a subdiscipline: If there are several modes of interpretation available, what are the advantages to hearing, conceiving, and describing the transformation of rhythmic-metric features in Brahms's scherzos as narratives, as opposed to just processes? What do these narratives contribute to the interpretation of these works?? Perhaps a more thorough response to these questions would require not only an extensive literature review of musicnarrative studies within the last thirty years, but also a comparison between these models and other analytical and hermeneutic frameworks that assist us in the interpretive process, taking into account what these frameworks allow us to say about the music and what they appear to marginalize. Suffice it to say for now that, if the narrative actually lies "outside" the music itself (as opposed to within) in the form of an "analytical fiction" that seeks to motivate readers to engage more closely with the music's perceived expressive meaning and dramatic action from another vantage point, then McClelland's narrative analyses of Brahms's scherzo-type movements fulfills this task. ${ }^{10}$

RENÉ Rusch

8 The analogy between musical and narrative structures has been discussed by Fred Maus in "Music as Narrative," Indiana Theory Review 12 (Spring-Fall 1991): 1-34.

9 In his review of Byon Almén's A Theory of Musical Narrative, Arnold Whittall has similarly proposed, "Yet it is also necessary to be persuaded that these [narrative] strategies contribute something valuable to the interpretation, something that might not otherwise emerge. Or is narrative analysis simply using different words to say something likely to have been said already?" (ibid., 301). Arnold Whittall, "A Theory of Musical Narrative," review in Music and Letters 91, no. 2 (May 2010): 299-303.

10 On the topic of how analytical prose can reveal different kinds of involvement with music, see Marion Guck, "Analytical Fictions," Music Theory Spectrum 16, no. 2 (Autumn 1994): 217-30. 